\title{
Battling the Invisible Infertility Agony: A Case Study of Infertile Women in Khyber Pakhtunkhwa-Pakistan By
}

\author{
Aman Ullah' ${ }^{\mathbf{1}}$ and Hina Ashraf \\ University of Swabi-Pakistan \\ Muhammad Tariq and Syed Zuhaib Aziz \\ University of Peshawar-Pakistan \\ Seema Zubair \\ The University of Agriculture Peshawar-Pakistan \\ Khalil Ur Rehman Sikandar \\ University of Peshawar-Pakistan \\ Nayab Ali \\ University of Swabi-Pakistan \\ Abdul Shakoor \\ Abdul Wali Khan University, Mardan-Pakistan \\ Muhammad Nisar \\ Bacha Khan University Charsadda-Pakistan
}

\begin{abstract}
This study's main theme is to explore the negative impact of women's infertility on their social life. Only those women who experienced infertility, both primary and secondary, and were currently seeking treatment for their infertility in different Private and Public hospitals/clinics in the study area were selected. Since the exact number of infertile women was unknown in the study area, purposive sampling was adopted while using snowballing techniques to find study participants. Rigorously following the snowball sampling method, data was collected from 400 respondents dealing with the agony of infertility through purposive sampling. Univariate, bivariate, and multivariate analyses were conducted. The findings indicated that gynaecological problems caused infertility issues that sometimes caused a miscarriage and led to secondary infertility. Moreover, infertility was a cause of deterioration in familial and social relationships. Likewise, infertility contributed to the feeling of social isolation and withdrawal from others. The provision of health services and the diffusion of information regarding infertility treatment and improving current health policies are recommendations based on the study's findings.
\end{abstract}

Keywords: causes, infertility, women, social impact, Pakistan.

\footnotetext{
${ }^{1}$ Corresponding Author E-Mail: Aman@uoswabi.edu.pk
} 
Infertility is an ailment of the reproductive system characterized by the failure to accomplish a clinical pregnancy after regular sexual intercourse for 12 months or more without using birth control procedures (Gurunath et al., 2011). Infertility is considered as primary when a woman has not conceived after two years of unprotected and properly timed intercourse, and secondary, when regardless of having a previous successful conception, a woman is unable to conceive afterwards, despite unregulated and properly timed intercourse for two years (Heikkurinen, 2019; Tabong \& Adongo, 2013).

No gender difference has been found regarding infertility triggers. Male and female variables account for $40 \%$ each, whereas the remaining $20 \%$ are either common or unidentified variables. Reduced sperm content, hormonal imbalance, varicocele, cryptorchidism, orchitis, and intercourse difficulties are some of the most frequently reported causes of childlessness in men. Widely accepted causes of infertility in the female are a disturbance in ovarian follicle growth, also known as ovulatory dysfunctions, structural defects of the uterus, and vaginismus (Brassard et al., 2008; Heikkurinen, 2019; Mustafa et al., 2019).

Infertility is an international phenomenon, and worldwide around 50 million couples experience infertility (Hodin, 2017). Moreover, in Pakistan, one-fifth of married couples experience infertility (Ali et al., 2011; Batool \& de Visser, 2016). However, infertility among women grew by $14.962 \%$ in an almost three-decade period, rising from 1366.85 per hundred thousand in 1990 to 1571.35 per hundred thousand in 2017 (Sun et al., 2019).

In most cultures, childbearing is directly associated with femininity and womanhood, and infertility is an unanticipated life crisis for women resulting in adverse societal disruptions and personal grief. It threatens the extended family expectations and hampers the enhancement of bonding believed to bind the spousal unit (Chang \& Mu, 2008; Inhorn \& Van Balen, 2002; Ismail \& Moussa, 2017; Loke et al., 2012). Being a patriarchal society, most Pakistani men had a fallacy about infertility, believing it a women's problem (Ali et al., 2011). Empirical studies in Pakistan have found that most infertile women have faced severe marital conflicts and were abused physically and verbally(Hakim et al., 2001). Infertility brings terrible ramifications in Pakistan, including domestic violence, a husband's re-marriage, and separation. Moreover, it can also contribute to social stigmatization in a society where infertility is viewed as role failure with social ramifications both on family and societal levels. Thus, infertility negatively influences a woman's life, including her marital life and social relations (Batool \& de Visser, 2016; Hakim et al., 2001; Ismail \& Moussa, 2017; Lindsey \& Driskill, 2013; Qadir et al., 2013; Rasool \& Zhang, 2020). Conceptually similar empirical work has also been carried out by Hassan et al. (2019) in which they explored that childless women are stigmatized in Baluchistan due to patriarchal mindset and rigid cultural values. Furthermore, infertility contributed to the feelings of loss, bring isolation for these childless women and negatively influence their social relationships.

Keeping these facts in mind, the present study explored the impacts of infertility on women's social status by collecting primary data from an area where women experience several challenges due to patriarchal values and discriminatory attitudes.

\section{Theoretical Framework}

Several theories explain the negative consequences of infertility on married women. However, the Biopsychosocial Theory of infertility presented by Gerrity (2001), is closely associated with the present empirical work. Moreover, the biopsychosocial postulate that human experience towards health or illness is significantly determined by the interaction of genetic makeup, psychological health, and sociocultural context. Thus infertility to be conceptualized as a severe life crisis and a failure along with deep-rooted complications for the individual, their spouse, 
relationship, family, and peer groups. He further added that Infertility stressors occur in the existential, physical, emotional, and interpersonal spheres and maybe beyond the usual coping abilities of the ordinary individual(Gerrity, 2001). Existential stressors indicated that infertility significantly influences individual self-esteem, self-image, and identity(Abbey et al., 1994; Bernstein et al., 1985; Bromham et al., 1989; Greil et al., 1989). Likewise, seeking medical treatment for infertility contributed to physical stressors(Blenner, 1990, 1992; Carmeli \& Birenbaum-Carmeli, 1994). The emotional effects of being infertile can have a significant effect on the individual, the couple, and the support network (Daniluk, 1988; Levin et al., 1997; Miall, 1994). Previous empirical work indicated that the emotional well-being of infertile women was lower than fertile women and infertile significantly boosts levels of stress among infertile women (Bernstein et al., 1985; Callan, 1987; Daniluk, 1988; Eisner, 1963; Freeman et al., 1987; Link \& Darling, 1986; O'Moore et al., 1983; Platt et al., 1973; Slade, 1981; Stephen Bell, 1981). Relationship stressors indicated that Infertility can contribute to severe marital problems and childless women often avoid interaction with others (Forrest \& Gilbert, 1992; Gerrity, 2001).

Biopsychosocial theory of infertility is suitable in the context of the study area in Pakistan. The implications of this theory strengthen and support the study finding. Furthermore, we add to theoretical arguments that the socio-cultural consequences are higher than other effects on infertile women in Pakistan. This is because of the prevalence of existing socio-cultural set-up which accelerates non-supportive attitudes toward infertile women

\section{Methodology}

\section{Research Design}

This study was conducted under the strategy of correlation study design. This design is often in the survey-based study for the purpose to sought out the association between study variables (Ullah et al., 2016).

\section{Universe, Sampling Procedure Sample, and Location of the Present Study}

The present study was conducted in the Mardan and Swabi districts of Khyber Pakhtunkhwa province to measure the social impact of infertility on married women. Only those women who had experienced both primary and secondary infertility and were currently seeking treatment for their infertility in different Private and Public hospitals/clinics in the abovementioned districts were selected. Because the exact number of infertile women was unknown in the study area, the study adopted purposive sampling while using snowballing techniques to find participants. Data were collected from 400 respondents (200 from each district) with the characteristics mentioned above. Interviews were conducted in the hospitals/clinics' waiting areas or a venue that the respondents proposed.

\section{Conceptual Framework of the Study}

A conceptual framework) was planned with an independent variable (Infertility among Women), dependent variables (Social impact and two background variables (age and educational status) See Table 1. 


\section{Table 1}

Conceptual Framework of the Study

\begin{tabular}{ccc}
\hline Background Variable & Independent Variable & Dependent Variable \\
\hline Age & Infertility & Social impact \\
Educational Status & & \\
\hline
\end{tabular}

\section{Operationalization}

The independent variable was infertility among married women. Its social impacts were the dependent variable, which was operationalized through statements derived from the prior empirical studies and expert views. Three medical and five social experts vetted these statements for suitability of these statements to measure the variable (content validity) and its logical order (construct validity). As a result, the measurement of infertility among women was based on ten statements, while the social impact of infertility was based on twelve items. Furthermore, the background variables for education status and age of the respondents were operationalized on a single item. See Table 2.

\section{Table 2}

Operationalization of the Variables

\begin{tabular}{ll}
\hline Variables & Operationalization \\
\hline Infertility & 1.Irregular menstrual cycle \\
2. Diagnosed with any gynaecological infection \\
3. Diagnosed with an obstruction in the tubes \\
4. Tried any other types of fertility treatments? IUI? IVF? ICSI? \\
5. The doctor advised you any medication to stimulate your ovaries \\
6. Infertility enhances with an increase in age \\
7. Anyone in your family has a history of infertility or hormonal imbalance \\
8. Obesity can cause infertility \\
1. Feel inferior \\
2. Do not attend social functions (related to childbirth \& naming) \\
3. Dishonored by couples having children within a joint setup \\
4. Being stigmatized \\
5. Deprived of the pleasures of parenthood \\
6. Sense of social alienation \\
7. Weakens the bond of marriage \\
8. Husband threats of second marriage \\
9. In-laws pressured the male partner for a 2nd marriage \\
10.Separation \\
11. Caused family conflicts \\
1. 18-23 \\
2. 24-29 \\
3. 30-35 \\
4. 36 and above \\
1. Literate \\
2. Illiterate \\
Ege
\end{tabular}




\section{Tools for Data Collection}

A structured interview was used for data collection, which covered the variables mentioned above. The statements were pre-tested with 30 participants between $15^{\text {th }}$ July and $10^{\text {th }}$. Inconsistencies and ambiguities in statements were altered, and some statements were removed before the collection of actual data. Additionally, a team of two females research investigators was trained in data collection.

\section{Ethical Considerations}

Prior consent of doctors /employer/ hospital administration was asked for permission to interview women seeking treatment at their hospitals and clinics. Likewise, prior informed consent of women was also obtained for conduction their interviews, and secrecy of data was ensured. Before the interview, the women were briefed regarding the purpose of the study and the importance of data gathered from them. Data were collected only from those women willing to take part in the process.

\section{Reliability Analysis and Indexation}

The process of merging two or more than two into a single item is called indexation. In the current study, an independent variable was indexed and then cross-tabulated with dependent variables at the bivariate level. In the multivariate analysis, both variables, i.e., independent and dependent, were indexed, while the women's age and education were used as background variables. Before indexation, Cronbach's alpha was executed for measuring the reliability of the study scale. The test results show that the value of both variables, e.g., women's infertility (independent) and social impact (dependent), was between 0.7 and 0.9. See Table 3

Table 3

Reliability Results of the Scale

\begin{tabular}{lcccc}
\hline Variables & $\begin{array}{c}\text { No. of } \\
\text { Statement }\end{array}$ & Mean & $\begin{array}{c}\text { Std. } \\
\text { Deviation }\end{array}$ & Cronbach's alpha \\
\hline Infertility & 08 & 12.1950 & 2.336798 & .71 \\
Social Impact & 11 & 13.6850 & 3.568278 & .86 \\
\hline
\end{tabular}

\section{Data Collection}

Data were collected from September 2019 to March 2020 using interviews by the two female research investigators in interview areas of the hospitals.

\section{Data Analysis}

Responses of the study participants were measured in the shape of frequency and percentage through Uni-variate analysis. The relationship between the independent variable and the dependent variable was determined through a Chi-square test, as defined by Ullah and Muhammad (2020). Multivariate analysis was also carried out for variations in social impacts due to infertility to determine whether age or the participant's educational status had an impact, as suggested by Ullah et al. (2020). All analyses were carried out through SPSS version 25. 


\section{Results}

\section{Demographic Profile}

Five age-slots were developed for the study. Thirty-six percent of the total respondents were between 30 to 35 years old. The results regarding participant education showed that the majority $(64.8 \%)$ of the respondents were literate, and $36.0 \%$ had been married between 2-5 years. About two-thirds of the participants experienced primary infertility, which meant the inability to have a successful live birth. While $33 \%$ of respondents said they had had a previous successful pregnancy but were currently unable to conceive. Among these women, $72.5 \%$ reported having received medical treatments for their infertility from private hospitals, while $25.5 \%$ of the respondents consulted government hospitals for infertility treatments. See Table 4 below.

\section{Table 4}

Demographic Profile of the Sampled Women

\begin{tabular}{|c|c|c|}
\hline Demographic profile & Frequency & Percent \\
\hline \multicolumn{3}{|l|}{ Age of the Participant } \\
\hline $18-23$ & 24 & 6.0 \\
\hline $24-29$ & 138 & 34.5 \\
\hline 30-35 & 144 & 36.0 \\
\hline 36 and above & 94 & 23.5 \\
\hline \multicolumn{3}{|l|}{ Education Status } \\
\hline Literate & 259 & 64.8 \\
\hline Illiterate & 141 & 35.3 \\
\hline \multicolumn{3}{|l|}{ Duration of Marriage } \\
\hline $2-5$ & 144 & 36.0 \\
\hline 6-10 & 113 & 28.3 \\
\hline 11 and above & 143 & 35.8 \\
\hline \multicolumn{3}{|l|}{ Type of Infertility } \\
\hline Primary & 268 & 67.0 \\
\hline Secondary & 132 & 33.0 \\
\hline \multicolumn{3}{|l|}{ Seeking Treatment in } \\
\hline Government Hospital & 102 & 25.5 \\
\hline Private Hospital & 290 & 72.5 \\
\hline Semi-Government Hospital & 8 & 2.0 \\
\hline 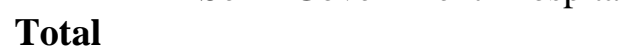 & 400 & 100 \\
\hline
\end{tabular}

\section{Infertility among Women}

All most all (82\%) of the participants experienced irregular menstruation problems and were diagnosed with a gynaecological infection (84.3\%). About two-thirds of the study (72.5\%) participants mentioned that they were not diagnosed with any obstruction in their fallopian tubes, and $62 \%$ never pursued expensive infertility treatments, including in vitro fertilization and intracytoplasmic sperm injection. More than half (56.3\%) of the participants stated that their doctor had advised them to take health supplements to enhance their fertility chances. In addition, most infertile women (56.3\%) said that age was a significant risk factor for infertility, mostly affecting women. Further, most respondents (78.5\%) disagreed that infertility was prevalent in their families, while about two-thirds (68\%) of the participant said that obesity could cause infertility. See Table 5 below. 
Table 5

Infertility Among Women

\begin{tabular}{|c|c|c|c|c|c|}
\hline $\begin{array}{l}\text { S. } \\
\text { No }\end{array}$ & Statement & Agreed & Disagreed & Uncertain & Total \\
\hline 1 & Irregular menstrual cycle & $\begin{array}{c}328 \\
(82 \%)\end{array}$ & $\begin{array}{c}66 \\
(16.5 \%)\end{array}$ & $\begin{array}{c}6 \\
1.5 \%)\end{array}$ & $\begin{array}{c}400 \\
(100 \%)\end{array}$ \\
\hline 2 & Diagnosed with any gynecological infection & $\begin{array}{c}337 \\
(84.3 \%)\end{array}$ & $\begin{array}{c}58 \\
(14.5 \%)\end{array}$ & $\begin{array}{c}5 \\
(1.3 \%)\end{array}$ & $\begin{array}{c}400 \\
(100 \%)\end{array}$ \\
\hline 3 & Diagnosed with an obstruction in the tubes & $\begin{array}{c}102 \\
(25.5 \%)\end{array}$ & $\begin{array}{c}290 \\
(72.5 \%)\end{array}$ & $\begin{array}{c}8 \\
(2 \%)\end{array}$ & $\begin{array}{c}400 \\
(100 \%)\end{array}$ \\
\hline 4 & $\begin{array}{l}\text { Tried any other types of fertility treatments? } \\
\text { IUI? IVF? ICSI? }\end{array}$ & $\begin{array}{c}119 \\
(29.8 \%)\end{array}$ & $\begin{array}{l}248 \\
(62 \%)\end{array}$ & $\begin{array}{c}33 \\
(8.3 \%)\end{array}$ & $\begin{array}{c}400 \\
(100 \%)\end{array}$ \\
\hline 5 & $\begin{array}{l}\text { The doctor advised you any medication to } \\
\text { stimulate your ovaries }\end{array}$ & $\begin{array}{c}227 \\
(56.8 \%)\end{array}$ & $\begin{array}{c}160 \\
(40 \%)\end{array}$ & $\begin{array}{c}13 \\
(3.3 \%)\end{array}$ & $\begin{array}{c}400 \\
(100 \%)\end{array}$ \\
\hline 6 & Infertility enhances with increase in age & $\begin{array}{c}225 \\
(56.3 \%)\end{array}$ & $\begin{array}{c}159 \\
(39.8 \%)\end{array}$ & $\begin{array}{c}16 \\
(4 \%)\end{array}$ & $\begin{array}{c}400 \\
(100 \%)\end{array}$ \\
\hline 7 & $\begin{array}{l}\text { Anyone in your family has a history of } \\
\text { infertility or hormonal imbalance }\end{array}$ & $\begin{array}{c}81 \\
(20.3 \%)\end{array}$ & $\begin{array}{c}314 \\
(78.5 \%)\end{array}$ & $\begin{array}{c}5 \\
(1.3 \%)\end{array}$ & $\begin{array}{c}400 \\
(100 \%)\end{array}$ \\
\hline 8 & Obesity can cause infertility & $\begin{array}{c}272 \\
(68 \%)\end{array}$ & $11(27.8 \%)$ & $\begin{array}{c}17 \\
(4.3 \%)\end{array}$ & $\begin{array}{c}400 \\
(100 \%)\end{array}$ \\
\hline
\end{tabular}

\section{Social Impacts of Infertility}

Table 6 shows that more than two-thirds $(70.3 \%)$ of the infertile women expressed the view that they felt inferior, and $69.8 \%$ said that they avoided participating in family gatherings that involved mothers. Nearly all $(92 \%)$ of the participants disclosed that they felt dishonored by couples having children within a joint setup, and $65 \%$ felt stigmatized. Moreover, $99.3 \%$ of the women opined that they were deprived of parenthood pleasures, and $83.8 \%$ said that they had developed a sense of social alienation. Also, $86 \%$ of the sampled women stated that infertility weakened the marriage bond, and $72 \%$ reported that their husbands had threatened a second marriage. Likewise, $71.3 \%$ reported that in-laws pressured the husband for a 2nd marriage. Most of $(81.3 \%)$ sampled women opined that infertility often led to separations, and $81 \%$ said infertility caused family conflict.

\section{Table 6}

Social Impacts of Infertility

\begin{tabular}{|c|c|c|c|c|c|}
\hline $\begin{array}{l}\text { S. } \\
\text { No }\end{array}$ & Statement & Agreed & Disagreed & Uncertain & Total \\
\hline 1 & Feel inferior & $\begin{array}{c}281 \\
(70.3 \%)\end{array}$ & $\begin{array}{c}87 \\
(21.8 \%)\end{array}$ & $\begin{array}{c}32 \\
(8 \%)\end{array}$ & $\begin{array}{c}400 \\
(100 \%)\end{array}$ \\
\hline 2 & Do not attend social functions & $\begin{array}{c}279 \\
(69.8 \%)\end{array}$ & $\begin{array}{c}100 \\
(25 \%)\end{array}$ & $\begin{array}{c}21 \\
(5.3 \%)\end{array}$ & $\begin{array}{c}400 \\
(100 \%)\end{array}$ \\
\hline 3 & $\begin{array}{l}\text { Dishonored by couples having children } \\
\text { within a joint setup }\end{array}$ & $\begin{array}{c}368 \\
(92 \%)\end{array}$ & $\begin{array}{c}29 \\
(7.3 \%)\end{array}$ & $\begin{array}{c}3 \\
(0.8 \%)\end{array}$ & $\begin{array}{c}400 \\
(100 \%)\end{array}$ \\
\hline 4 & Being stigmatized & $\begin{array}{c}260 \\
(65 \%)\end{array}$ & $\begin{array}{c}117 \\
(29.3 \%)\end{array}$ & $\begin{array}{c}23 \\
(5.8 \%)\end{array}$ & $\begin{array}{c}400 \\
(100 \%)\end{array}$ \\
\hline 5 & Deprived of the pleasures of parenthood & $\begin{array}{c}397 \\
(99.3 \%)\end{array}$ & $\begin{array}{c}1 \\
(0.3 \%)\end{array}$ & $\begin{array}{c}2 \\
(0.5 \%)\end{array}$ & $\begin{array}{c}400 \\
(100 \%)\end{array}$ \\
\hline
\end{tabular}




\begin{tabular}{|c|c|c|c|c|c|}
\hline 6 & Sense of social alienation & $\begin{array}{c}335 \\
(83.8 \%)\end{array}$ & $\begin{array}{c}63 \\
(15.8 \%)\end{array}$ & $\begin{array}{c}2 \\
(0.5 \%)\end{array}$ & $\begin{array}{c}400 \\
(100 \%)\end{array}$ \\
\hline 7 & Weakens the bond of marriage & $\begin{array}{c}344 \\
(86 \%)\end{array}$ & $\begin{array}{c}47 \\
(11.8 \%)\end{array}$ & $\begin{array}{c}9 \\
(2.3 \%)\end{array}$ & $\begin{array}{c}400 \\
(100 \%)\end{array}$ \\
\hline 8 & Husband threats of second marriage & $\begin{array}{c}288 \\
(72 \%)\end{array}$ & $\begin{array}{c}98 \\
(24.5 \%)\end{array}$ & $\begin{array}{c}14 \\
(3.5 \%)\end{array}$ & $\begin{array}{c}400 \\
(100 \%)\end{array}$ \\
\hline 9 & $\begin{array}{l}\text { In-laws pressured the male partner for a } \\
\text { 2nd marriage }\end{array}$ & $\begin{array}{c}285 \\
(71.3 \%)\end{array}$ & $\begin{array}{c}96 \\
(24 \%)\end{array}$ & $\begin{array}{c}19 \\
(4.8 \%)\end{array}$ & $\begin{array}{c}400 \\
(100 \%)\end{array}$ \\
\hline 10 & Separation & $\begin{array}{c}325 \\
(81.3 \%)\end{array}$ & $\begin{array}{c}57 \\
(14.3 \%)\end{array}$ & $\begin{array}{c}18 \\
(4.5 \%)\end{array}$ & $\begin{array}{c}400 \\
(100 \%)\end{array}$ \\
\hline 11 & Caused family conflicts & $\begin{array}{c}324 \\
(81 \%) \\
\end{array}$ & $\begin{array}{c}59 \\
(14.8 \%) \\
\end{array}$ & $\begin{array}{c}17 \\
(4.3 \%)\end{array}$ & $\begin{array}{c}400 \\
(100 \%)\end{array}$ \\
\hline
\end{tabular}

\section{Association Between Infertility and Social Impacts}

Table 7 presents the association between the independent variable (infertility) and the dependent variable (social impact). The results show that infertility was a significant determinant of the feeling of inferiority among women $(p=0.000)$. Likewise, infertility significantly affected women's participation in social functions, particularly related to childbirth and naming $(\mathrm{p}=0.000)$. Similarly, infertility was found to be highly significant with disgrace in the joint family by a fertile couple $(p=0.000)$. Furthermore, infertility significantly contributed to stigmatization and the development of a sense of social alienation $(p=0.000)$. In addition, the pleasure of parenthood was found insignificantly related to infertility $(p=0.916)$. Infertility significantly $(p=0.000)$ weakened the bond of marriage and positively $(\mathrm{p}=0.000)$ enhanced the threat of 2 nd marriages by their husbands. Likewise, infertility among women significantly was associated with in-laws pressuring a husband for 2 nd marriage $(\mathrm{p}=0.000)$. Similarly, the association between separation and infertility was also found highly significant $(\mathrm{p}=0.000)$. Moreover, infertility significantly caused family conflicts $(\mathrm{p}=0.000)$.

\section{Table 7}

Association Between Infertility and Social Impacts

\begin{tabular}{|c|c|c|c|c|c|}
\hline \multirow[t]{2}{*}{ S, no } & \multirow[t]{2}{*}{ Infertility } & \multicolumn{3}{|c|}{ Social Impact } & \multirow[t]{2}{*}{ Statistic } \\
\hline & & Agreed & Disagreed & Neutral & \\
\hline \multirow[t]{5}{*}{1} & & & Feel Inferior & & \multirow{5}{*}{$\begin{array}{c}x^{2}=111.886 \\
p=0.000\end{array}$} \\
\hline & Agree & 199(70.8\%) & $12(13.8 \%)$ & $4(12.5 \%)$ & \\
\hline & Disagree & $76(27 \%)$ & $69(79.3 \%)$ & $27(84.4 \%)$ & \\
\hline & Neutral & $6(2.1 \%)$ & $6(6.9 \%)$ & $1(3.1 \%)$ & \\
\hline & Total & $281(100 \%)$ & $87(100 \%)$ & $32(100 \%)$ & \\
\hline \multirow[t]{5}{*}{2} & Do not & attend social $f$ & tions (related & rth \& naming) & \multirow{5}{*}{$\begin{array}{c}x^{2}=51.381 \\
p=0.000\end{array}$} \\
\hline & Agree & $169(60.6 \%)$ & $43(43 \%)$ & $3(14.8 \%)$ & \\
\hline & Disagree & $110(39.4 \%)$ & $45(45 \%)$ & $17(81 \%)$ & \\
\hline & Neutral & $0(0 \%)$ & $12(12 \%)$ & $1(4.8 \%)$ & \\
\hline & Total & $279(100 \%)$ & $100(100 \%)$ & $21(100 \%)$ & \\
\hline \multirow[t]{4}{*}{3} & \multicolumn{4}{|c|}{ Dishonored by couples having children within a joint setup } & $x^{2}=147.349$ \\
\hline & Agree & $2014(55.4 \%)$ & $8(27.6 \%)$ & $3(100 \%)$ & $p=0.000$ \\
\hline & Disagree & $163(44.3 \%)$ & $9(31 \%)$ & $0(0 \%)$ & \\
\hline & Neutral & $1(0.3 \%)$ & $12(41.4 \%)$ & $0(0 \%)$ & \\
\hline
\end{tabular}




$\begin{array}{lll}\text { Total } & 368(100 \%) & 29(100 \%)\end{array}$

4

$\begin{array}{lcc} & & \text { Being stigmatized } \\ \text { Agree } & 210(67.5 \%) & 47(662 \%) \\ \text { Disagree } & 101(32.5 \%) & 16(22.5 \%) \\ \text { Neutral } & 0(0 \%) & 13(20.6 \%) \\ \text { Total } & 335(100 \%) & 63(100 \%)\end{array}$

5

$\begin{array}{lccc}\text { Agree } & 213(53.7 \%) & 1(100 \%) & 1(50 \%) \\ \text { Disagree } & 171(43.1 \%) & 0(0 \%) & 1(50 \%) \\ \text { Neutral } & 13(3.3 \%) & 0(0 \%) & 0(0 \%) \\ \text { Total } & 397(100 \%) & 1(100 \%) & 2(100 \%)\end{array}$

6

\begin{tabular}{lccc}
\multicolumn{3}{c}{ Sense of social alienation } \\
Agree & $210(62.7 \%)$ & $4(6.3 \%)$ & $1(50 \%)$ \\
Disagree & $125(37.3 \%)$ & $46(73 \%)$ & $1(50 \%)$ \\
Neutral & $0(0 \%)$ & $8(11.3 \%)$ & $15(83.3 \%)$ \\
Total & $335(100 \%)$ & $63(100 \%)$ & $2(100 \%)$
\end{tabular}

7

$\begin{array}{lccc}\text { Agree } & 195(56.7 \%) & 18(38.3 \%) & 2(22.2 \%) \\ \text { Disagree } & 149(43.3 \%) & 21(44.7 \%) & 2(22.2 \%) \\ \text { Neutral } & 0(0 \%) & 8(17 \%) & 5(55.6 \%) \\ \text { Total } & 344(100 \%) & 47(100 \%) & 9(100 \%)\end{array}$

8

$\begin{array}{lcc}\text { Agree } & 153(53.1 \%) & 62(63.3 \%) \\ \text { Disagree } & 128(44.4 \%) & 30(30.6 \%) \\ \text { Neutral } & 7(2.4 \%) & 6(6.1 \%) \\ \text { Total } & 288(100 \%) & 98(100 \%)\end{array}$

$$
\begin{gathered}
3(16.7 \%) \\
0(0 \%) \\
0(0 \%) \\
2(100 \%)
\end{gathered}
$$$$
x^{2}=116.599
$$$$
p=0.000
$$

$$
x^{2}=0.955
$$$$
p=0.916
$$

$$
x^{2}=116.599
$$$$
\boldsymbol{p}=\mathbf{0 . 0 0 0}
$$

$x^{2}=119.615$

$p=0.000$

$$
\begin{aligned}
x^{2} & =26.950 \\
p & =0.000
\end{aligned}
$$

\begin{tabular}{|c|c|c|c|c|}
\hline & & Separation & & \\
\hline Agree & $203(62.5 \%)$ & $11(19.3 \%)$ & $1(5.6 \%)$ & $x^{2}=106.140$ \\
\hline Disagree & $122(37.5 \%)$ & $34(59.6 \%)$ & $16(88.9 \%)$ & $p=0.000$ \\
\hline Neutral & $0(0 \%)$ & $12(21.1 \%)$ & $1(5.6 \%)$ & \\
\hline Total & $325(100 \%)$ & $57(100 \%)$ & $18(100 \%)$ & \\
\hline
\end{tabular}

\begin{tabular}{|c|c|c|c|c|}
\hline \multicolumn{5}{|c|}{ Causes family conflicts } \\
\hline Agree & $202(62.3 \%)$ & $12(20.3 \%)$ & $1(5.9 \%)$ & $x^{2}=101.760$ \\
\hline Disagree & $122(37.7 \%)$ & $35(59.3 \%)$ & $15(88.2 \%)$ & $p=0.000$ \\
\hline Neutral & $0(0 \%)$ & $12(20.3 \%)$ & $1(5.9 \%)$ & \\
\hline Total & $324(100 \%)$ & $59(100 \%)$ & $17(100 \%)$ & \\
\hline
\end{tabular}

\section{9}

In-laws pressure the male partner for 2 nd marriage

$\begin{array}{lcccc}\text { Agree } & 200(70.2 \%) & 9(9.4 \%) & 6(31.6 \%) & \boldsymbol{x}^{\mathbf{2}=\mathbf{1 2 7 . 6 6 3}} \\ \text { Disagree } & 85(29.8 \%) & 77(80.2 \%) & 10(52.6 \%) & \boldsymbol{p}=\mathbf{0 . 0 0 0} \\ \text { Neutral } & 0(0 \%) & 10(10.4 \%) & 3(15.8 \%) & \\ \text { Total } & 285(100 \%) & 96(100 \%) & 19(100 \%) & \end{array}$

10

11 
Ullah, A.

\section{Association Between Infertility and Social Impacts (Controlling for Age)}

The results of multivariate analysis in Table 8 show that the influence of infertility among women on social life in the context of the participant's age was insignificant $(p=0.503)$ relationship in the for the age group of 18-23 years. However, the abovementioned variables' relationship was found highly significant $(\mathrm{p}=0.000)$ for the group of $24-29$ years and 30 years and above. Thus, results from the age group of 24-29 years and 30 and above years revealed a negative relationship between infertility and social life impact.

\section{Table 8}

Association Between Infertility and Social Impacts (Controlling for Age)

\begin{tabular}{|c|c|c|c|}
\hline Age Group & $\begin{array}{c}\text { Independent } \\
\text { variable }\end{array}$ & Dependent variable & Statistics \\
\hline $18-23$ & Infertility & Social impact & $\begin{array}{c}x^{2}=1.375 \\
p=0.503\end{array}$ \\
\hline $24-29$ & Infertility & Social impact & $\begin{aligned} x^{2} & =30.098 \\
p & =0.000\end{aligned}$ \\
\hline 30 and above & Infertility & Social impact & $\begin{aligned} x^{2} & =52.900 \\
p & =0.000\end{aligned}$ \\
\hline
\end{tabular}

\section{Association Between Infertility and Social Impacts (Controlling for Education)}

Results of multivariate analysis in Table 9 disclosed that the impact of infertility among women on the social life in the context of study participants' education disclosed a strongly significant relationship for an illiterate and literate group $(p=0.000)$. Thus, the findings for illiterate and literate show a negative relationship between infertility and social life impact.

Table 9

Association Between Infertility and Social Impacts (Controlling for Education)

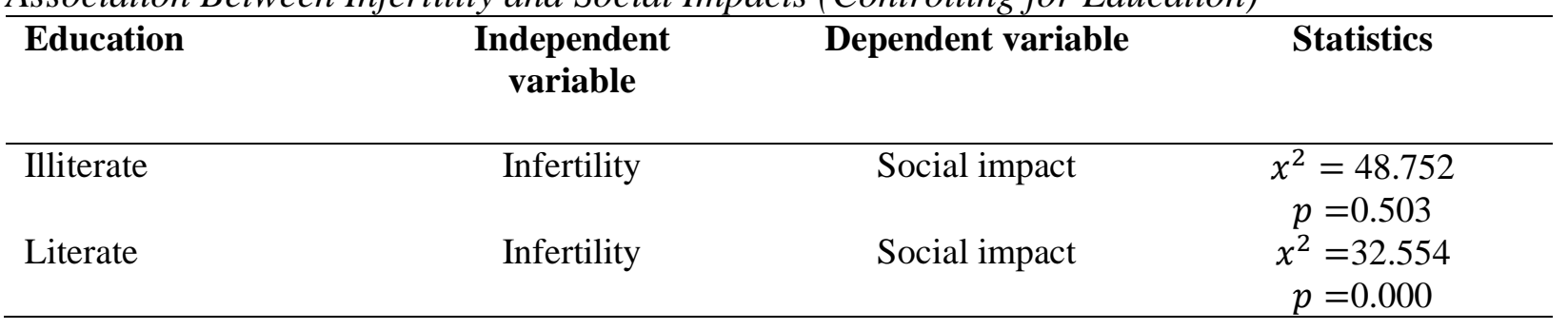

\section{Discussion}

The family system has historically followed a hierarchical order in Pakistani society, where loyalty and compliance to the elders are still of greatest priority; the male members ultimately govern the family and are responsible to carry on the family name. It is, therefore, very important to have a son as an heir in the Pakistani family context. In this regard, the present study endeavored to examine the impact of infertility on women's health, relation with husband, and other social ties. It is hard to convey the experience of infertility when it interferes with almost every facet of her life bringing her guilt, disappointment, and problems of understanding with her husband and the larger society as well as economic instability. The participant's demographic characteristic showed that a major proportion of the respondents experienced primary infertility, which showed their 
failure to have a successful live birth. At the same time, a significant number of respondents reported a previous successful pregnancy but were currently unable to conceive. Study findings revealed that the primary reason for infertility was polycystic ovary syndrome (PCOS), which is a cause of irregular menstruation. They were not diagnosed with any obstruction in the tubes. It could be attributed to the fact infertility is a multi-faced health issue which not only caused by health problems such as salpinx, oviduct, gonaduct, and the endometrium but significantly affected by lifestyle, like marriage in old age, stress, and lack of health facilities pertaining to reproduction, etc. (Roupa et al., 2009).

Most had undergone extensive infertility examinations, including many physical examinations, laparoscopy, and hysteron salpingography (HSG) to examine for tubal blockage. However, study participants did not pursue expensive infertility treatments. Similar findings were also explored by Roupa et al. (2009) that due to the high cost of treatment females with low income have little access to reproduction treatments. The in vitro fertilization and intracytoplasmic sperm injection, though available in developed countries, are available only to the more affluent urban elite in Pakistan and are extremely costly for low-income families. A recent study by Muhammad and Begum (2018) reconfirmed that infertility treatment is a very costly and laborious process that further worsens their problems in Pakistan. In addition, women in Khyber Pakhtunkhwa are discouraged to discuss the issue of infertility openly or only discussed with elder women of the family due to cultural values and often restricted from medical treatment. Similarly, mostly women used homemade remedies to cure their infertility problems. Similar findings were also explored by Nguyen et al. (2018) who reported that Asian women dwelling in the U.S. mostly consult their family members and peer groups when encountering domestic issues and give more importance to their opinion. The present study found that obstetric or gynecological problems cause infertility issues in women that sometimes cause a miscarriage and also lead to secondary infertility. In this context, their doctor has advised them health supplements to enhance their chances of fertility. Respondents report several causes of infertility. Age was seen as a significant risk factor for infertility, mostly affecting women as older women are more likely to have fertility issues than younger women. The sampled women did not report any infertility history or hormonal imbalance cases within the nearest family ties. This result indicates that they did not attribute their infertility to genetic problems. Lastly, women reported that they felt that obesity was related to infertility. These findings closely align with (Roupa et al., 2009).

The findings revealed several social implications. First, infertile women feel stigmatized and ridiculed in their families and their communities most of the time. Due to cultural values, women are primarily blamed for the couple's infertility even if the problem is not from her side. This intensifies the negative effects on her personal and social status. These findings closely align with (Rouchou, 2013) and (Papreen et al., 2000), who reported that childlessness brings social difficulties. Infertile women are victimized and stigmatized. Second, these women avoid participating in family gatherings that involve mothers. Due to public questioning of their infertility, they often do not attend such gatherings. Previous studies also reported that most of the time women's infertility contributed to their social marginalization, exclusion, and stigmatization (Gillespie, 2000; Letherby, 2000; Park, 2002). Third, infertility also brings about discrimination, even from her husband's relatives. These findings closely align with the following empirical work (Jansen \& Saint Onge, 2015; Lakatos et al., 2017; Namavar Jahromi et al., 2018), they indicated that Infertility triggered numerous biological, mental health, and societal implication, including anxiety, stigma, social isolation, and humiliation which inversely associated with women fertility. Fourth, sharing love and caring for a child is a unique sentiment that tightens the knot of the marriage that deepens by having a child, fulfilling the eventual goal of life for couples. Fifth, 
infertility can be highly devastating because it is perceived as a complete role failure for both partners because every man takes a wife to have children to preserve the family name and for social approval. Therefore, the wives try endlessly to ensure the birth of a child. Sixth, when this focal expectation of the marriage tie does not occur, the husbands, under tremendous family pressure, upset the wife with the repeated threats of a second marriage. Lastly, when the female has to endure the major impact of the blame for the couples' childless state, this often results in family conflicts and the dissolution of marriage. These findings are amplifying by the recent empirical work of (Dierickx et al., 2018) that Infertility negatively influences women's lives in their family-in-law, and also confronted psychological and corporeal violence in their marriage.

At the multivariate level, the influence of infertility among women on social life age had ab insignificant association in the variables described above for the age group 18-23 years old. However, the abovementioned variables' relationship was highly significant for the group of 24-29 years and 30 years and above. As already mentioned, women felt that age was a contributing factor for infertility, mostly affecting women. Thus, the women at a young age are assumed to be fertile, which certainly less affects their social status than those women who are older. Likewise, the impact of infertility among women on social life in the context of participants' education disclosed a strongly significant relationship for both the illiterate and literate groups. However, the above findings negate the existing empirical work of (Dierickx et al., 2018) that the educational qualification of women decreases negative social implications caused by their infertility. This finding could be attributed to the fact that in Pakistani society, the primary role of females is a reproduction, and failing to reproduce significantly adversely affected their social life, even for those having a higher education qualification. Thus the prevalent rigid cultural values and normative practices are used against infertile women in Pakistani society that prone women to many violence including physical and non-physical (Zarar et al., 2017). However, the empirical work of Merhaut (2019) reported that women in Roma experience prejudicial treatment in all walks of life that negatively affected their quality of life. Taking together, study findings and prior work it could be affirmed that cultural values and practices not only affected women's lives in Pakistan but also in other parts of the world too.

\section{Contribution of Biopsychosocial Theory of Infertility in Amplification the Findings of the Study}

The theoretical framework of the present study validates the broader application of the Biopsychosocial Theory of infertility (Gerrity, 2001) based on the outcome of the study. Findings of this theory are closely associated with the outcome of the present study. In sum, results of the present study help to conclude that the social impact of infertility on married women could be sufficiently describing under the Biopsychosocial Theory of infertility. However, the present study has made innovative contributions in the above-mentioned theory by using literacy status and age of the respondents as background variables.

\section{Conclusion, Limitations, and Recommendations}

Procreation is strongly considered normal and expected in almost all the cultures around the globe, infertility is deemed to be a specific cause of deterioration at personal as well as at family levels. The study's findings suggest that infertile women in the study area faced stigmatization and discernment, keeping in view their failure to reproduce from their family and other social circles. A sense of social isolation and withdrawal from others develops with growing time, as their personal identity becomes unimportant while the identity as infertile becomes central. 
The problem is more of a serious concern when the spousal relationship gets negatively affected by the trauma. Moreover, the in-law's ridicule towards the female partner, repeated threats of the second marriage, and economic insecurity in the future bring huge disturbances in the life of an infertile female. Consistent with previous findings, this study has certain limitations. First, this study was purely quantitative. Understanding the problem under investigation more deeply requires a qualitative study. Second, the study's scope was confined to assess the impact of infertility only on women in the study area while the male partner was not investigated, which certainly limited the applicability of the findings. However, this work is a major contribution to the existing literature on infertility implications in a society, where women are considered subordinate and treated unfairly. Based on study findings following are some recommendations;

- Compassionate and prompt treatment must be prescribed for those suffering from infertility, keeping in view the mechanisms through which their experiences have been influenced and formed by the socio-cultural context in which they dwell.

- The findings of the present study will be helpful in policy making regarding women's health and other developing program focusing on women's problems.

- It is recommended that the health system should review current strategies and find methods to strengthen fertility care for the benefit of infertile couples. An increased opportunity to obtain other infertile women for the medication and the probability of success is also expected.

- The government and other stakeholders should develop health policies and start health service at the doorstep in less developed areas for women, especially for those seeking infertility treatment. That is because in these areas, women are restricted to the four walls of houses, and they have little access to outside. Likewise, awareness through local leaders and religious leaders will help disseminate information regarding local people's attitude formation regarding women's treatment of infertility.

\section{References}

Abbey, A., Andrews, F. M., \& Halman, L. J. (1994). Psychosocial predictors of life quality: How are they affected by infertility, gender, and parenthood? Journal of Family Issues, 15(2), 253-271. https://doi.org/10.1177/0192513X94015002006

Ali, S., Sophie, R., Imam, A. M., Khan, F. I., Ali, S. F., Shaikh, A., \& Farid-ul-Hasnain, S. (2011). Knowledge, perceptions and myths regarding infertility among selected adult population in Pakistan: A cross-sectional study. BMC Public Health, 11(1), 760. https://doi.org/10.1186/1471-2458-11-760

Batool, S. S., \& de Visser, R. O. (2016). Experiences of infertility in British and Pakistani women: A cross-cultural qualitative analysis. Health Care for Women International, 37(2), 180-196. https://doi.org/10.1080/07399332.2014.980890

Bernstein, J., Potts, N., \& Mattox, J. H. (1985). Assessment of psychological dysfunction associated with infertility. Journal of Obstetric, Gynecologic, \& Neonatal Nursing, 14(s6), 63s-66s. https://doi.org/10.1111/j.1552-6909.1985.tb02803.x

Blenner, J. L. (1990). Passage through infertility treatment: A stage theory. Image: The Journal of Nursing Scholarship, 22(3), 153-158. https://doi.org/10.1111/j.1547-5069.1990.tb00199.x

Blenner, J. L. (1992). Stress and mediators: Patients' perceptions of infertility treatment. Nursing Research, 41(2), 92-97. https://doi.org/10.1097/00006199-199203000-00007 
Brassard, M., AinMelk, Y., \& Baillargeon, J. -P. (2008). Basic infertility including polycystic ovary syndrome. Medical Clinics of North America, 92(5), 1163-1192. https://doi.org/10.1016/j.mcna.2008.04.008

Bromham, D., Bryce, F., Balmer, B., \& Wright, S. (1989). Psychometric evaluation of infertile couples (preliminary findings). Journal of Reproductive \& Infant Psychology, 7(4), 195202. https://doi.org/10.1080/02646838908403594

Callan, V. J. (1987). The personal and marital adjustment of mothers and of voluntarily and involuntarily childless wives. Journal of Marriage \& the Family, 847-856. https://doi.org/10.2307/351978

Carmeli, Y. S., \& Birenbaum-Carmeli, D. (1994). The predicament of masculinity: Towards understanding the male's experience of infertility treatments. Sex Roles, 30(9), 663-677. https://doi.org/10.1007/BF01544669

Chang, S. N., \& Mu, P. F. (2008). Infertile couples' experience of family stress while women are hospitalized for ovarian hyperstimulation syndrome during infertility treatment. Journal of Clinical Nursing, 17(4), 531-538. https://doi.org/10.1111/j.1365-2702.2006.01801.x

Daniluk, J. C. (1988). Infertility: Intrapersonal and interpersonal impact. Fertility \& Sterility, 49(6), 982-990. https://doi.org/10.1016/S0015-0282(16)59948-8

Dierickx, S., Rahbari, L., Longman, C., Jaiteh, F., \& Coene, G. (2018, 2018/09/12). 'I am always crying on the inside': A qualitative study on the implications of infertility on women's lives in urban Gambia. Reproductive Health, 15(1), 151. https://doi.org/10.1186/s12978-018$0596-2$

Eisner, B. G. (1963). Some psychological differences between fertile and infertile women. Journal of Clinical Psychology, 19(4), 391-395. https://doi.org/10.1002/10974679(196310)19:4<391::AID-JCLP2270190403>3.0.CO;2-R

Forrest, L., \& Gilbert, M. S. (1992). Infertility: An unanticipated and prolonged life crisis. Journal of Mental Health Counseling, 14(1), 42-58.

Freeman, E. W., Rickels, K., Tausig, J., Boxer, A., Mastroianni, L., \& Tureck, R. W. (1987). Emotional and psychosocial factors in follow-up of women after Ivf-Et treatment: A pilot investigation. Acta Obstetricia et Gynecologica Scandinavica, 66(6), 517-521. https://doi.org/10.3109/00016348709015727

Gerrity, D. A. (2001). A biopsychosocial theory of infertility. The Family Journal, 9(2), 151-158. https://doi.org/10.1177/1066480701092009

Gillespie, R. (2000). When no means no: Disbelief, disregard and deviance as discourses of voluntary childlessness. Women's Studies International Forum, 23(2), 223-234. https://doi.org/10.1016/S0277-5395(00)00076-5

Greil, A. L., Porter, K. L., Leitko, T. A., \& Riscilli, C. (1989). Why me? Theodicies of infertile women and men. Sociology of Health \& Illness, 11(3), 213-229.

Gurunath, S., Pandian, Z., Anderson, R. A., \& Bhattacharya, S. (2011). Defining infertility-A systematic review of prevalence studies. Human Reproduction Update, 17(5), 575-588. https://doi.org/10.1093/humupd/dmr015

Hakim, A., Sultan, M., \& Ahmad, F. (2001). Pakistan Reproductive Health and Family Planning Survey (2000-01): Preliminary report. National Institute of Health (NIH), Park Road. https://www.nips.org.pk/abstract_files/Pakistan\%20Reproductive\%20Health\%20Family\% 20Planning\%20Survey\%202000-01\%20_Preliminary\%20Report.pdf

Hassan, S. -U. -N., Siddiqui, S., \& Friedman, B. D. (2019). Health status and quality of life of women seeking infertility treatments in Baluchistan, Pakistan. The British Journal of Social Work, 50(5), 1401-1418. https://doi.org/10.1093/bjsw/bcz130 
Heikkurinen, S. (2019). Missed children: A descriptive literature review on the effects of involuntary childlessness on a heterosexual couple's relationship and sexuality [Bachelor's thesis, Lahti University Of Applied Sciences]. https://www.theseus.fi/bitstream/handle/10024/168915/Heikkurinen_Sanni.pdf

Hodin, S. (2017, 12 November ). The burden of infertility: Global prevalence and women's voices from around the world. Maternal Health Task Force. https://www.mhtf.org/2017/01/18/theburden-of-infertility-global-prevalence-and-womens-voices-from-around-theworld/\#: : text=Available\%20data\%20indicate\%20that\%20at\%20least $\% 2050 \% 20$ million $\% 20$ couples $\% 20$ worldwide $\% 20$ experience $\% 20$ infertility.\&text=According $\% 20$ to $\% 20$ a $\%$ 20 systematic\%20analysis,roughly\%202\% $25 \% 20$ experienced\%20primary\%20infertility.

Inhorn, M., \& Van Balen, F. (2002). Infertility around the globe: New thinking on childlessness, gender, and reproductive technologies. University of California Press.

Ismail, N., \& Moussa, A. (2017). Coping strategies and quality of life among infertile women in Damanhour City. Journal of Nursing \& Health Science, 6(2), 31-45. https://doi.org/10.9790/1959-0602083145

Jansen, N. A., \& Saint Onge, J. M. (2015). An internet forum analysis of stigma power perceptions among women seeking fertility treatment in the United States. Social Science \& Medicine, 147, 184-189. https://doi.org/10.1016/j.socscimed.2015.11.002

Lakatos, E., Szigeti, J. F., Ujma, P. P., Sexty, R., \& Balog, P. (2017). Anxiety and depression among infertile women: A cross-sectional survey from Hungary. BMC Women's Health, 17(1), 48. https://doi.org/10.1186/s12905-017-0410-2

Letherby, G. (2000). Images and representation of non-motherhood. Reproductive Health Matters, 8(16), 143-143. https://doi.org/10.1016/S0968-8080(00)90197-6

Levin, J. B., Sher, T. G., \& Theodos, V. (1997). The effect of intracouple coping concordance on psychological and marital distress in infertility patients. Journal of Clinical Psychology in Medical Settings, 4(4), 361-372. https://doi.org/10.1023/A:1026249317635

Lindsey, B., \& Driskill, C. (2013). The psychology of infertility. International Journal of Childbirth Education, 28(3), 41-47.

Link, P. W., \& Darling, C. A. (1986). Couples undergoing treatment for infertility: Dimensions of life satisfaction. Journal of Sex \& Marital Therapy, 12(1), 46-59.

Loke, A. Y., Yu, P. L., \& Hayter, M. (2012). Experiences of sub-fertility among Chinese couples in Hong Kong: A qualitative study. Journal of Clinical Nursing, 21(3-4), 504-512. https://doi.org/10.1111/j.1365-2702.2010.03632.x

Merhaut, M. (2019). Theoretical studies focused on gender discrimination against Roma women in the Czech Republic. Journal of Ethnic \& Cultural Studies, 6(1), 28-44. http://doi.org/10.29333/ejecs/147

Miall, C. E. (1994). Community constructs of involuntary childlessness: Sympathy, stigma, and social support. Canadian Review of Sociology [Revue canadienne de sociologie], 31(4), 392-421. https://doi.org/10.1111/j.1755-618X.1994.tb00828.x

Muhammad, D., \& Begum, N. (2018). Health and social issues of infertile women in Pakistan. Annals of Allied Health Sciences, 4(2), 31-32.

Mustafa, M., Hadi, J., Iiizam, E., \& Sani, A. (2019, 09/01). Male and female infertility: Causes, and management. IOSR Journal of Dental \& Medical Sciences, 18(9), 27-32. https://doi.org/10.9790/0853-1809132732

Namavar Jahromi, B., Mansouri, M., Forouhari, S., Poordast, T., \& Salehi, A. (2018). Quality of life and its influencing factors of couples referred to an infertility center in Shiraz, Iran. 
Ullah, A.

International Journal of Fertility \& Sterility, 11(4), 293-297. https://doi.org/10.22074/ijfs.2018.5123

Nguyen, P., Corona, R., DeCarlo, M. P., Yaros, A., Le, A. T., \& Compton, K. (2018). Help seeking behavior in a diverse sample of Asian American adults. Journal of Ethnic \& Cultural Studies, 5(2), 1-15. http://doi.org/10.29333/ejecs/124

O'Moore, A. M., O'Moore, R. R., Harrison, R. F., Murphy, G., \& Carruthers, M. E. (1983). Psychosomatic aspects in idiopathic infertility: Effects of treatment with autogenic training. Journal of Psychosomatic Research, 27(2), 145-151. https://doi.org/10.1016/00223999(83)90091-0

Papreen, N., Sharma, A., Sabin, K., Begum, L., Ahsan, S. K., \& Baqui, A. H. (2000). Living with infertility: Experiences among urban slum populations in Bangladesh. Reproductive Health Matters, 8(15), 33-44. https://doi.org/10.1016/S0968-8080(00)90004-1

Park, K. (2002). Stigma management among the voluntarily childless. Sociological Perspectives, 45(1), 21-45. https://doi.org/10.1525/sop.2002.45.1.21

Platt, J. J., Ficher, I., \& Silver, M. J. (1973). Infertile couples: Personality traits and self-ideal

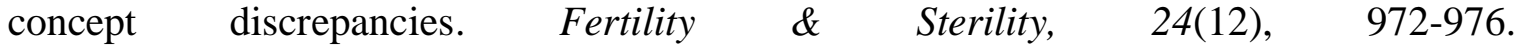
https://doi.org/10.1016/S0015-0282(16)40097-X

Qadir, F., Khalid, A., Haqqani, S., \& Medhin, G. (2013). The association of marital relationship and perceived social support with mental health of women in Pakistan. BMC Public Health, 13(1), 1-13. https://doi.org/10.1186/1471-2458-13-1150

Rasool, S., \& Zhang, J. (2020). Bangladeshi, Indian, and Pakistani Parents' Perceptions of Their Children's Academic Achievement in Southwest Florida. American Journal of Qualitative Research, 4(3), 146-160. https://doi.org/10.29333/ajqr/9337

Rouchou, B. (2013). Consequences of infertility in developing countries. Perspectives in Public Health, 133(3), 174-179. https://doi.org/10.1177/1757913912472415

Roupa, Z., Polikandrioti, M., Sotiropoulou, P., Faros, E., Koulouri, A., Wozniak, G., \& Gourni, M. (2009). Causes of infertility in women at reproductive age. Health Science Journal, 3(2), 80-87.

Slade, P. (1981). Sexual attitudes and social role orientations in infertile women. Journal of Psychosomatic Research, 25(3), 183-186. https://doi.org/10.1016/0022-3999(81)90031-3

Stephen Bell, J. (1981). Psychological problems among patients attending an infertility clinic. Journal of Psychosomatic Research, 25(1), 1-3. https://doi.org/10.1016/00223999(81)90077-5

Sun, H., Gong, T. -T., Jiang, Y. -T., Zhang, S., Zhao, Y. -H., \& Wu, Q.-J. (2019). Global, regional, and national prevalence and disability-adjusted life-years for infertility in 195 countries and territories, 1990-2017: Results from a global burden of disease study, 2017. Aging (Albany NY), 11(23), 10952. https://doi.org/10.18632/aging.102497

Tabong, P. T. -N., \& Adongo, P. B. (2013). Infertility and childlessness: A qualitative study of the experiences of infertile couples in Northern Ghana. BMC Pregnancy \& Childbirth, 13(1), 72. https://doi.org/10.1186/1471-2393-13-72

Ullah, A., Ashraf, H., \& Shah, M. (2016). Understanding perceptions about the role of traditional practices regarding inheritance with relation to inheritance feud settlement: A case study of District Mardan Khyber Pakhtunkhwa-Pakistan. Journal of Ethnic \& Cultural Studies, 3(2), 1. http://doi.org/10.29333/ejecs/55

Ullah, A., \& Muhammad, N. (2020). Prevalence of mental health problems among youth involved in street crimes. Rawal Medical Journal, 45(4), 938-942. 
Ullah, A., Muhammad, N., Ullah, M. S., Ishaq, M. R., Ali, M. A., Farah, M., Jawad, M., \& Aziz, S. Z. (2020). Media role in up surging the youth participation in street crimes. PalArch's Journal of Archaeology of Egypt/Egyptology, 17(6), 14157-14163.

Zarar, R., Bukhsh, M., \& Khaskheli, W. (2017). Causes and consequences of gender discrimination against women in Quetta City. Arts \& Social Sciences Journal, 8(3), 1-6.

\section{Notes on Contributors}

Mr. Aman Ullah is working as Head of the Sociology/ Psychology Department, the University of Swabi since 2017. He not only established the department of psychology but also strived to turn it into one of the vibrant and stalwart departments of the university. His work takes place at sites of intersection and interconnection, between disciplines and fields of criminology, gender studies, and Sociology of development. Mr, Ullah has done his M.Phil. in sociology from Agriculture University Peshawar with distinction and currently pursuing his Ph.D. from the University of Peshawar.

Miss Hina Ashraf serving as Lecturer in the Department of Sociology, University of Swabi Pakistan. She did her M.Phil. in sociology from the University of Peshawar. Her area of specialization is medical Sociology.

Mr. Muhammad Tariq has done his M.Phil. in the discipline of Sociology. Currently, he is enrolled in Ph.D. Program at Department of the Sociology University of Peshawar Pakistan. MDGs, SDGs, and medical sociology are the special areas of his interest with a special focus on Social Development.

Mr. Syed Zuhaib Aziz has been working in the Health Department, Government of Punjab, Pakistan since 2010. He did his Masters in Sociology from Bahauddin Zakariya University, Multan, Pakistan, and M. Phil. Sociology from the same university. He is currently doing his Ph.D. from the Department of Sociology, University of Peshawar, Pakistan. His research interests include Medical Sociology, Family, Criminology, and Gender Issues.

Dr. Seema Zubair did her Ph.D. in statistics from Carleton university Canada. Her area of specialization is semi-parametric models, longitudinal data, missing data, GEE, WGEE, nonparametric, and spline techniques. Currently, she is working as a lecturer in the Department of Maths State and Computer Science, University of Agriculture Peshawar Pakistan.

Mr. Khalil Ur Rehman Sikandar currently pursuing his Ph.D. from the University of Peshawar. His area of specialization is Medical Sociology, Family, Criminology, and Gender Issues.

Dr. Nayab Ali did his Ph.D. in Rural Sociology from the University of Agriculture Peshawar Pakistan. Currently serving as Lecturer in the Department of Sociology, University of Swabi Pakistan. His area of specialization is the Sociology of development.

Dr. Abdul Shakoor completed his Ph.D. degree from the University of Peshawar, Pakistan, in 2015. His asperities social reconstruction. Currently, he is working as an Assistant Professor in the Department of International Relations, Abdul Wali Khan University, Mardan, KhyberPakhtunkhwa, Pakistan.

Mr. Muhammad Nisar is working Lecturer in the Department of Sociology, Bacha Khan University Charsadda. Pakistan. Currently pursuing his Ph.D. in Rural Sociology from the University of Agriculture Peshawar Pakistan. 